\begin{tabular}{c}
$\begin{array}{c}\text { ホ研究者育成 } \\
\text { 成果報告 }\end{array}$ Hosokawa Powder Technology Foundation ANNUALREPORT \\
\hline
\end{tabular}

\title{
15508
}

\section{ホタテ貝款粉体を用いた放射線污染水処理剤の開発 \\ Development of Radiation Contaminated Water Treatment Agent Using Scallop Shell Powder}

\author{
援助対象者 Scholarship Student: 三原 史寛 Fumihiro MIHARA \\ 東京理科大学大学院 理工学研究科工業化学専攻 \\ 博士後期課程 1 年 \\ Graduate school of pure and applied chemistry, Tokyo University of Science, \\ PhD Student (D1) \\ E-mail: 7216709@ed.tus.ac.jp
}

\section{研究指導者 Academic Leader： 竹内 謙 Ken TAKEUCHI}

教授, Professor

E-mail: ken@rs.kagu.tus.ac.jp

\section{成 果 の 概 要}

\section{研究背景}

ホタテガイの水揚げ量は毎年約 50 万トン（農 林水産省，2016）で，その内およそ25万トン の貝殼が産業廃衰物となっている。ホ夕テガイ 養殖量の多い北日本において貝殼の処理は大き な問題であり，その利用法を模索する必要があ る。現在, 廃棄されているホ夕テ貝殼の一部は $\mathrm{CaCO}_{3}$ の原料としてチョークや土壌改良剤等 に使われている。しかし, 年間 2 億トン（牧雄 一郎ら，2000）が産出されている石灰岩がすで に $\mathrm{CaCO}_{3}$ の原料として用いられているため, 貝殼由来の製品は普及が進んでいない。普及を 促進させるためには，ホ夕テ貝殼特有の性質を 見出し, 製品に反映させる必要がある。一方で, 2016 年 4 月の原発に関する報告書（東京電力, 2016）によると福島第一原発周辺には約 80 万 トンの污染水が蓄積し, その処理が問題となっ
ている，污染水には $\mathrm{Cs}$ や $\mathrm{Sr}$ 等の放射性物質が 含まれており，己れらを効率良く回収すること がその処理の鍵となる。特に放射性物質の中で も人体に残存しやすく，より危険な $\mathrm{Sr}^{2+}$ を吸 着する技術の開発が急がれるが, 既存の吸着剤 は環境負荷が高くコストがかかる。そこで我々 は安価で安全なホ夕テ貝殼を原料とした吸着剤 の作成を試み, 粉砕したホタテ貝殼が水溶液中 の $\mathrm{Sr}^{2+}$ を除去できることを見いだした（Mihara F. et al., 2015)。本報告では，ホ夕テ貝殼の $\mathrm{Sr}^{2+}$ 除去剂としての可能性を検証した研究結果につ いて記す。

\section{実験方法}

北海道産ホタテガイから身を取り除いた貝殼 を材料として用いる。貝殼から污れを取り除き， 超音波洗浄機で 60 分洗浄を行った. 乾燥させ たホタテ貝殼 $60 \mathrm{~g}$ を数 $\mathrm{cm}$ 角に割り, スタンプ ミル（nitto 社, ANS-143）に入れ, ホタテ貝殼 
を $3 \mathrm{~h}$ 粉砕し粉末状にした. さらに, 粉末粒径 を小さくするために自動乳鉢（nitto 社, AMM1400）を用いて $3 \mathrm{~h}$ 粉砕し, 粒径を揃えるため に分級機（Retsch 社, AS2000）を用いてふる い分けした：ふるいによって分けられた25$53 \mu \mathrm{m}$ の粒径をもつ粉末を実験に使用した。ま た, 石灰岩もスタンプミルでの粉砕以降, 同様 の操作を行い粉末作成した. 次にその粉体の表 面積を BET 比表面積測定装置で測定した。ま た，粉末作成時に用いた自動乳鉢は，粉砕時間 を変化させてそれらの粉末の $\mathrm{Sr}^{2+}$ 吸着能を調 ベた。作成した粉末を $\mathrm{SrCl}_{2}$ 水溶液に加え懸濁 させた。所定時間毎に懸濁液を濾過し, 濾液中 の $\mathrm{Sr}^{2+}$ 濃度を原子吸光光度計 $(\mathrm{AA})$ で測定した。

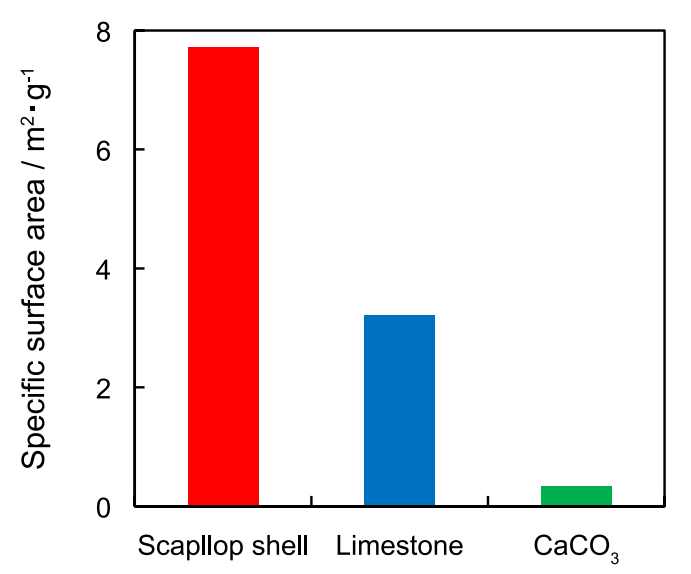

Fig. 1 Comparison of specific surface area.

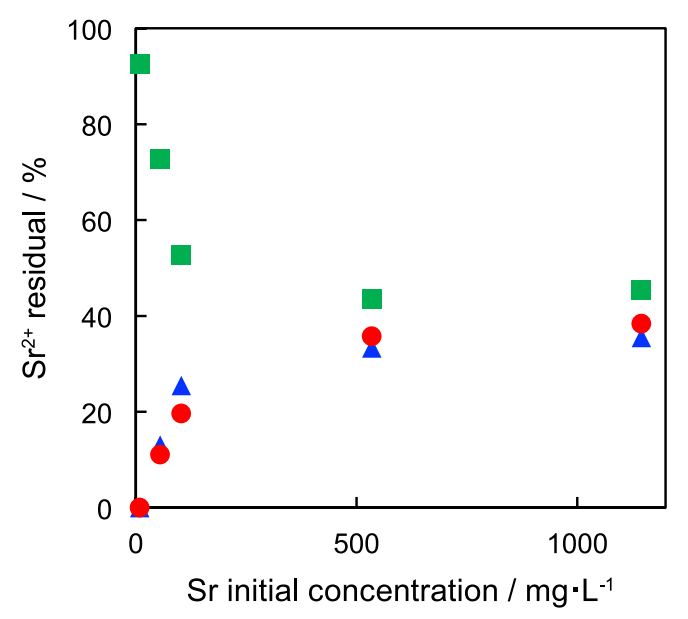

Fig. 2 Initial concentration of $\mathrm{Sr}^{2+}$ dependent on capability of removing $\mathrm{Sr}^{2+}$.

\section{成果詳細}

表面積の測定結果（Fig. 1) より, $\mathrm{CaCO}_{3}$ の 市販試薬と比べ, ホタテ貝殼は約 10 倍の比表 面積を有していた。

一般に, 比表面積が大きいほど吸着能が高い. そこで，ホタテ貝殼を吸着剂に応用できると考 え, 吸着実験を行った。 ホ夕テ貝殼粉末を様々 な濃度の $\mathrm{SrCl}_{2}$ 水溶液に加えて懸濁させ, 所定 時間毎に採取した濾液中の $\mathrm{Sr}^{2+}$ 残留率の測定 を行い, $\mathrm{Sr}^{2+}$ 吸着能を評価した. Fig. 2 より $500 \mathrm{mg} \cdot \mathrm{L}^{-1}$ 以下の濃度域において試薬 $\mathrm{CaCO}_{3}$ と ホ夕テ貝殼, 石灰岩が異なる吸着性能を示した。

この濃度部分においては, 試薬 $\mathrm{CaCO}_{3}$ には

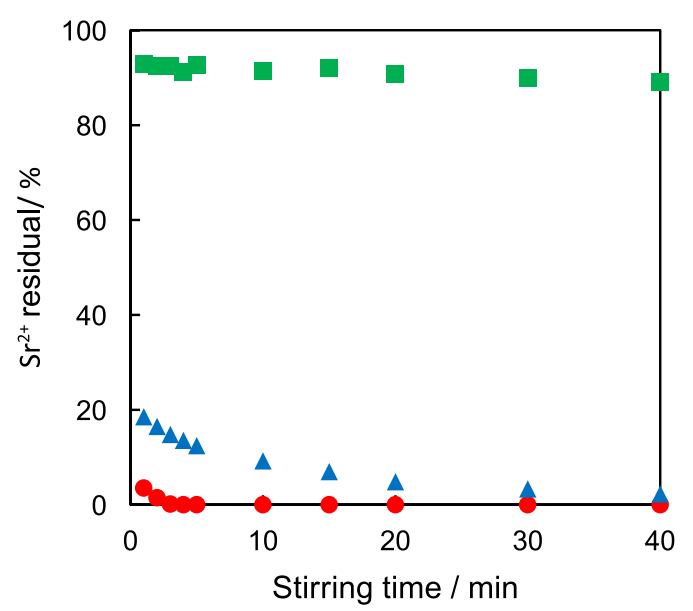

Fig. $3 \mathrm{Sr}^{2+}$ residual $\%$ in the solution as a function of suspension time.

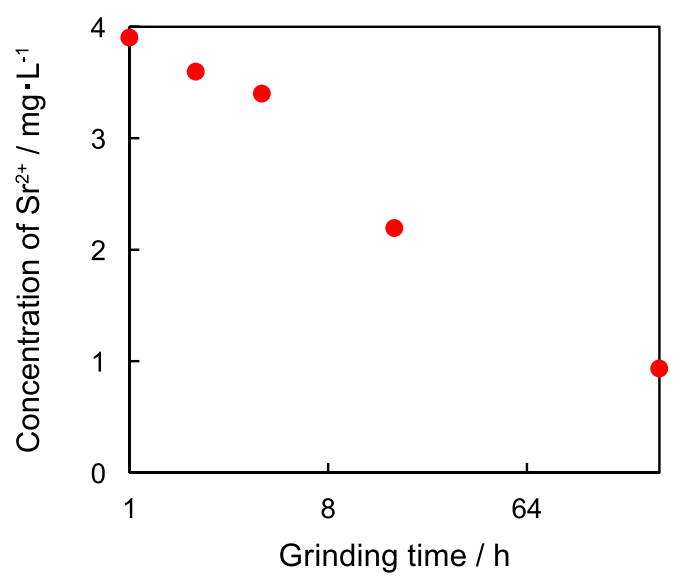

Fig. 4 Grinding time dependent on capability of removing $\mathrm{Sr}^{2+}$. 
ないホタテ貝殼にしか発揮されない特性がある と推測される。そこで, ホタテ貝殼粉末を $\mathrm{Sr} 10 \mathrm{mg} \cdot \mathrm{L}^{-1}$ の $\mathrm{SrCl}_{2}$ 水溶液に加えて懸濁させ, 所定時間毎に採取した滤液中の $\mathrm{Sr}^{2+}$ 残留率の 測定を行い, $\mathrm{Sr}^{2+}$ 吸着能を評価した。

Fig. 3 のようにホ夕テ貝喨粉末は, 濃度 $10 \mathrm{mg} \cdot \mathrm{L}^{-1}$ の $\mathrm{Sr}^{2+}$ を 3 分間で $\mathrm{AA}$ の検出限界以 下 $\left(0.01 \mathrm{mg} \cdot \mathrm{L}^{-1}\right)$ まで下げることができた。 ホ 夕テ貝殼が他の 2 物質と異なる性能を示したこ とについて, 貝殼を粉砕する工程を疑った。 そ こで, 自動乳鉢による粉砕時間と $\mathrm{Sr}^{2+}$ 吸着性 能の関係性を検証した。

Fig. 4 に示すように粉砕時間が増加するにつ れ, $\mathrm{Sr}^{2+}$ 吸着性能が向上する傾向がみられた。

\section{外部発表成果}

\section{論文発表}

1. Mihara F., Takeuchi K., Tamura S., Idemoto Y., Kogo Y., The Use of Scallop Shell Powder as a Method of Extracting Strontium, MRS Advances, First View Article (2016) 1-8.

\section{口頭・ポスター発表}

1. 三原史寛, 秋山好嗣, 竹内 謙, 井手本康, “水溶液中に扔けるホタテ貝殼粉末の $\mathrm{Sr}$ イ
今後, 粉体表面の状態が $\mathrm{Sr}^{2+}$ 吸着性能に及ぼ す影響を研究していく予定である.

\section{参考文献}

[1] Mihara F., Takeuchi K., Tamura S., Idemoto Y., Kogo Y., The Use of Scallop Shell Powder as a Method of Extracting Alkaline-Earth Metals, ECS Transactions, 66 (2015), 9-13

[2] 牧雄一郎, 松本仁之, “石灰石鉱業の現状と課題”, 地質ニュース， 547, p. 23-35 (2000).

[3] 農林水産省, 平成 27 年漁業 - 養殖業生産統計, p. 3-4 (2016). http://www.maff.go.jp/j/tokei/kouhyou/ kaimen_gyosei/pdf/gyogyou_seisan_15_1.pdf

[4] 東京電力, 廃炉 - 污染水対策の概要, p. 5 (2016). http://www.tepco.co.jp/nu/fukushima-np/roadmap/ images1/images2/d161027_05-j.pdf

オン吸着特性”, 第 30 回日本吸着学会研究 発表会（Nagasaki, Nov.10-11, 2016） P-27.

2. 三原史寛, 竹内 謙, “ホ夕テ貝殼粉末を利 用した $\mathrm{Sr}$ イオンの回収”平成 28 年度青函 水産試験研究交流会議（Hokkaido, Dec.1213, 2016).

3. Mihara F., Takeuchi K., Tamura S., Kogo Y., Idemoto Y., "Mechanism of removing $\mathrm{Sr}^{2+}$ by using scallop shell powder" 5th International Conference on Multifunctional, Hybrid and Nanomaterials (Lisbon, Portugal, Mar.610,2017) P1.108. 